\title{
Obituary
}

\section{Sir Wilfred Cockcroft 1923-1999}

Although Bill Cockcroft was by training a professional mathematician, it will be as a larger than life character who also made his mark in education that he will be remembered. But, first, a brief outline of his life.

Born the son of a plumber in Keighley, he attended Keighley Grammar School before going up to Balliol College in Oxford. The second world war, in which he served in the RAF in the far east, interrupted his career. He then lectured in Aberdeen and Southampton before obtaining a chair at Hull in 1961. His next move was to establish, as Vice-Chancellor, the New University of Ulster in Coleraine in 1976. He left Northern Ireland in 1982 and, in 1983, became the chairman and chief executive of the new Secondary Examinations Council in London which, by the time he retired in 1988 , had developed the new GCSE. He was knighted in 1983, an event not unconnected with his Committee of Inquiry into the teaching of mathematics which resulted in the highly praised report Mathematics Counts published in 1982.

Although born Wilfred Halliday Cockcroft, he was always known as Bill at home and later by everyone who knew him. The first impression when meeting Bill Cockcroft was of a bluff Yorkshire man. He was a big man, larger than life, friendly and a bon viveur. He loved conversation, music, theatre, food and drink He always had a fund of amusing, and usually true, stories. His flamboyant style carried with it a unique Falstaffian rumbustiousness. We remember the West Riding bellow of his voice, the gales of his laughter and his guffaws. Conversations were intense, full of pauses, and the variety of ways he had for saying 'I don't know', expressing sorrow, disgust, ignorance, mystification and much else in different tones of voice. If you knew him at the height of his powers, you would marvel at his stamina for work and play, notably his legendary capacity for strong drink. Such characteristics made him a vital presence in any gathering, political, academic or domestic.

Bill was totally unpompous and without malice. He made friendships unconstrained by class, race or wealth. He is probably the only ViceChancellor to play golf with the Head Porter and the Estates Manager of his university. Apocryphally, the fourth player was his driver with special duties for the golfcart. On these forays at Portstewart Golf Club, it was alleged, Danny McGryllis's task was to shepherd enough bottles of Guinness around the course to enable the winner of the hole either to be toasted at the point of his victory or to enjoy a bottle in solitary celebration.

But teachers will remember him for Mathematics Counts which Bill, mischievously but not seriously, suggested should be entitled A Feeling For Figures. For me, it was an exhilarating experience to be a member of the committee of inquiry. When the Secretary of State for Education, Shirley Williams, set up the committee in 1978, it was assumed that a quick report would ensue but it was two Secretaries of State later when Keith Joseph 
received the report. Bill was unflappable. The government had to wait until he felt that the shape of the report was clear and that there was evidence to support all the statements. The rapport engendered within the committee was such that, to mark each anniversary of the completion of the report, a reunion was held at an Italian restaurant in London with, of course, large quantities of wine!

Members of the Cockcroft committee were allowed to discuss at length until a consensus was reached. It was rare to have a vote. It was interesting that Keith Joseph was so completely satisfied with the academic rigour and persuasive evidence that, from the publication of the Cockcroft Report in early 1982, we saw a resurgence of confidence in the teaching of mathematics. We had a blueprint which was widely accepted as the way forward and the funding, including the advisory teachers known as 'Cockcroft missionaries' and a significant boost to the Association's Diploma courses, to help carry it out.

Again, Bill was to influence mathematics teachers when he oversaw the introduction of the new GCSE. The Cockcroft Committee had, based on work at Chelsea College and in particular Kath Hart's CSMS project, become convinced that the curriculum should be 'bottom-up', building on the Foundation List rather than the traditional watering down of a curriculum for the most able. A particular concern, over which Sir Keith Joseph agonised, was the least able $40 \%$ who often left school with little positive achievement to show.

The principle enshrined in the bottom-up approach is that all pupils should be successful and have a sense of achievement. Too often pupils obtain a 'certificate of success' knowing that they did not answer correctly most of the questions on the examination paper. The notion of competence was becoming important, for example, in reassuring an employer that a certificate was at least a minimal guarantee of attainment. The SEC continued this work by attempting to identify the criteria of 'Success' at particular grades.

Bill was such a colourful and energetic character that many more pages could be filled by this obituary. I hope that others will write to the editor with further tales of the unique Cockcroft qualities. He is sorely missed by everyone that knew him.

\section{Acknowledgement}

Some of the above material is taken from a memorial talk given at his funeral by Hugh Sockett, a friend and colleague from Bill's days in Coleraine.

PETER REYNOLDS 6 Rosebery Road, Felixstowe IP11 7JR 